\title{
Assessment of the histrionic self-presentation style: initial validation of the Polish version of the As-If-Scale
}

\author{
Agnieszka Fanslau $\mathbb{D}^{1 \cdot A, B, E, F}$, Pawet furek (D) ${ }^{1 \cdot A, C, D}$, Karl-Heinz Renner $\mathbb{( D}^{2 \cdot E, F}$ \\ 1: Institute of Psychology, University of Gdansk, Gdansk, Poland \\ 2: Bundeswehr University Munich, Munich, Germany
}

\section{BACKGROUND}

The main research objective was to translate and evaluate the Polish version of the As-If-Scale (AIS) as well as to test the measurement invariance of the Polish and the original (German) versions of the tool, and to analyze the differences in histrionic self-presentation style among Poles and Germans. The AIS consists of 8 items for the subjective assessment of the histrionic self-presentation style which involves behaviors such as playing roles, imitating people or even engaging others in performing small role-plays, and is seen as an individual difference phenomenon.

\section{PARTICIPANTS AND PROCEDURE}

The psychometric properties of the Polish version were tested in two samples with a total of 762 participants.

\section{RESULTS}

The article presents the factor structure and reliability of the scale. In addition, the AIS was correlated with mea- sures of the Big Five personality traits, pragmatism and gelotophobia to provide initial validation. Measurement invariance was tested using data collected in this study (Polish sample) and existing and previously published data (German sample).

\section{CONCLUSIONS}

Overall, the results provide support for the reliability of the scale as its properties are similar to those of the German version. The findings also allow one to make broader cross-cultural comparisons of the histrionic self-presentation style, which includes various types of behavior and is often associated with humor.

KEY WORDS

humor; histrionic self-presentation style; cross-national comparison

Corresponding AUthor - Agnieszka Fanslau, Ph.D., Institute of Psychology, University of Gdansk, 4 Bażyńskiego Str., 80-309 Gdansk, Poland, e-mail: agnieszka.fanslau@ug.edu.pl

AUthors' CONTRIBUtion - A: Study design - B: Data collection - C: Statistical analysis - D: Data interpretation .

E: Manuscript preparation · F: Literature search · G: Funds collection

TO CITE this ARTICLE - Fanslau, A., Jurek, P., \& Renner, K. H. (2021). Assessment of the histrionic self-presentation style:

initial validation of the Polish version of the As-If-Scale. Current Issues in Personality Psychology, 9(2), 165-178.

RECEIVED 30.10.2020 · REVIEWED 07.12.2020 • ACCEPTED 18.01.2021 · PUBLISHED 12.04.2021 


\section{BACKGROUND}

Effective self-presentation is one of the most crucial skills in human social life as social rewards depend on how others perceive us (Schlenker, 1980; Baumeister, 1982). Countless studies prove that thanks to self-presentational strategies people achieve multiple goals: they engage in romantic relationships, attain professional success, gain admiration or respect (Goffman, 1959; Schlenker \& Pontari, 1973; Jones \& Pittman, 1982; Leary, 1995; Dupree \& Fiske, 2019). Moreover, making a favorable impression (i.e. desired identity images) thanks to self-presentational strategies can help individuals raise their self-esteem and improve self-evaluations (Jones et al., 1981; Baumeister, 1982), achieve self-fulfillment (Rogers \& Dymond, 1954; Cohen, 1959), and evoke positive emotions (Scopelliti et al., 2015). Self-presentation embraces behaviors planned to make a desired impression on others (Vohs et al., 2005), such as otherreinforcement, praise, doing favors, consensus of opinion, similarity expression, and diverse indirect forms of self-descriptions of attributions for achievement, including (infrequent) complaining (Alicke et al., 1992; Jones \& Pittman, 1982; Kowalski, 1996, 2002), displaying humility (Jones \& Wortman, 1973) or even humblebragging (Sezer et al., 2018). Effective self-presentation requires good acting abilities: abilities to convincingly communicate inner states through expressive channels - facial expressions, gestures, posture, voice modulation, and other cues - in the actual absence of the internal states. Most expressive control may be undertaken to make the social interaction run smoothly - out of concern for the situational appropriateness and desired public appearance. However, some people could also wish to "go beyond deceiving" their audience (where the interaction partners do not perceive their behaviors as role-plays), behave more theatrically, and therefore try to transform daily situations into dramatic scenes.

\section{HISTRIONIC SELF-PRESENTATION}

The term histrionic derives from the Latin word histrio (which means an actor), and is usually associated with a specific personality disorder. It is characterized by a ubiquitous pattern of over-emotionality and attention seeking. Some of the main criteria include feeling uncomfortable in situations in which one is not the center of attention, rapidly changing and shallow expression of emotions, theatricality, self-dramatization and excessive expression of emotions, speech that is extremely impressionistic and unclear, or consistent use of physical appearance to draw attention to oneself (American Psychiatric Association, 2013). Renner et al. (2008), however, put histrionic personality in a non-pathological context and define histrionic self-presentation as "a way of shaping everyday interactions by explicit As-If behaviors" (Renner et al., 2008, p. 1303). As-If behaviors are specific forms of impression management in a social setting. They involve quick changes between different roles, imitating different people or characters, or even engaging other people in performing small role-plays. As-If behaviors can be performed through different channels - verbal, non-verbal or paraverbal, single or multiple - and encompass facial expressions, gestures, posture, using metaphors, irony or amusing word games, rolling one's eyes or voice modulation. They can take both exaggerated (e.g. jumping up and imitating characters) as well as more subtle forms (using irony or metaphors only). Tension creation (attracting attention and fascinating an audience) and tension reduction (relieving stress, reducing anger or chances of conflict escalation) seem to be the basic motives to perform As-If behaviors (Renner et al., 2008; Renner \& Heydasch, 2010). In other words, histrionic self-presenters view everyday situations as chances for role-playing and for altering such situations into "dramatic scenes" in order to seek the attention of others, entertain them, liven up the atmosphere, manipulate mood and/or ease tension in oneself and an audience. They play roles and they want to give the impression that they do so, unlike (pure) pragmatists, whose main target is to adjust to the situation. The latter regard themselves as flexible individuals who adjust their behavior to situational demands (and their own goals). They regard their behavior as a means of presenting themselves. Such people construct their own behavior with a strong regard to the situation in which it is to take place. They are sensitive to the cues in a situation which indicate what expression or selfpresentation is appropriate and what is not (Wojciszke, 1984). As high self-monitors, they pay attention to the social adequacy of their own behavior, pay attention to others for guidance on a desired course of action, and are able to control and modify their expressive behavior (Snyder, 1974). They show a greater initiative in contacts with new people and undertake more actions to facilitate the course of social interactions (e.g. Szmajke, 1995; Gangestad \& Snyder, 2000). As-If performers are high selfmonitors as well, but while pragmatists act in order to meet the requirements of a given situation, histrionic self-presenters do not always act appropriately. By explicit As-If behaviors they take a risk of being perceived as too theatrical, exaggerated or even mad. The tendency and ability to act at all, which lies at the heart of self-monitoring, is a necessary but not a sufficient condition for histrionic self-presentation. Thus, not every individual high in self-monitoring will be a histrionic self-presenter (Renner et al., 2008). 
Histrionic role-plays are not meant to be taken seriously, as they often involve joking, teasing or playing around. This evident relationship between humor and histrionic self-presentation is also proved by positive associations of the construct with gelotophilia (the joy of being laughed at), and katagelasticism (the joy of laughing at others) (Renner \& Heydasch, 2010). Furthermore, histrionic self-presentation (along with gelotophilia) is related to the quantitative and qualitative humor generating abilities as measured in the Cartoon Punch Line Production Test (Renner \& Manthey, 2018). By contrast, gelotophobia (the fear of being laughed at) reveals a negative correlation with histrionic self-presentation style (Renner \& Heydasch, 2010). The term gelotophobia was proposed by Michael Titze (1996), a German psychotherapist who described some of his patients as permanently and persistently worried of being laughed at. He defines gelotophobia (gelos is Greek for laughter) as the pathological fear of appearing as a ridiculous object to social partners, and describes the origins and consequences of the phenomenon, such as an experience of bullying or mobbing for the former, and social withdrawal, low self-esteem and psychosomatic disturbances for the latter (for details see: Ruch \& Proyer, 2008a, b; Titze, 2009). Gelotophobes feel extremely uncomfortable when exposing themselves to others and are characterized by negative reactions towards laughter. They become suspicious when hearing laughter from their social partners as well as from strangers whose joyful laughter is heard incidentally (Ruch et al., 2009). Therefore, they cannot experience laughter (and laughter of others in particular) as something relaxing and positive. While Titze coined his definition of gelotophobia within a clinical realm, many empirical studies carried out so far show that gelotophobia is of relevance in nonclinical populations as well. Therefore, it should be interpreted as an individual difference phenomenon at a sub-clinical level (Ruch \& Proyer, 2008a; Platt, 2008). Gelotophobes are less cheerful, often perform a socially cold humor style, do not use humor as a means to cope with adversity and rarely involve themselves in self-enhancing and affiliative humor (Ruch et al., 2009). Their low self-esteem is reflected in protective, self-depreciating self-presentation styles (Renner \& Heydasch, 2010; Radomska \& Tomczak, 2010), which involve presenting themselves as incompetent, insecure and helpless individuals, who are responsible for multiple failures that affect them. Such tactics are designed to minimize the expected negative impact of the situation they found themselves in on the self-image they created.

Humor, creativity, and extraversion have been found to be positively correlated (Koppel \& Sechrest, 1970). Extraverts are described as sociable, lively, active, assertive, tending to enjoy human interactions, and enthusiastic, talkative, and gregarious (Dionigi,
2016). Studies on humor have proved that extraverts are more cheerful, less serious, and able to produce a higher quantity of humor content (Köhler \& Ruch, 1996). Moreover, high extraversion is associated with the desire to be at the center of social attention. Openness to experience is also positively associated with humor production ability. It involves the motivation to engage in unconventional, witty ways of presenting a story. People higher in openness are more creative and better than others at being funny (Martin \& Ford, 2018). The evidence for the role of openness to experience in humor production ability is not at all surprising, considering that this personality trait is closest to intellectual ability and creativity (DeYoung et al., 2007). Neuroticism on the other hand is made up of traits such as being anxious, depressed, feeling guilty, having low self-esteem, irrationality and shyness. Moreover, it is negatively correlated with cheerfulness (Köhler \& Ruch, 1996). Anxious individuals are more susceptible to focusing on potential threat in their environment (Eysenck \& Derakshan, 2011), and high neuroticism in performers leads to stronger stage fright (Steptoe et al., 1995). The relationship between agreeableness, conscientiousness and humor is somewhat more complex. Cheerful people are, in general, more agreeable and less conscientious (Ruch \& Hofmann, 2012), like volunteer clown doctors, whose main goal is to assist hospital patients in the healing process, distract them from distressing procedures, reduce anxiety caused by hospitalization, and improve their mood (high agreeableness relates to their ability to be responsive and sensitive towards other people's needs) (Dionigi, 2016). On the other hand, a lot of comedians and professional stand-up performers are neither agreeable nor conscientious. They sometimes aim at teasing others through mockery and ridicule (Greengross et al., 2011), tend to be ideologically provocative and verbally aggressive on stage, which may be perceived as unfriendly or even hostile (Greengross \& Miller, 2009). And despite the fact that the affiliative humor style predicts their professional success, they often score highly on negative (aggressive and self-defeating) humor styles as well (Greengross et al., 2011).

Humor is one of the most important traits for humans seeking mates. Verbal humor is widely used in social situations and plays an important role in attracting mates, especially for men (Lundy et al., 1998). Research shows that men are more fluent in their humor production ability (e.g. produce larger number of captions) than women, and women are more responsive to and discriminating about humor (Bressler \& Balshine, 2006). In other words, when selecting a mate, men use humor more often and more imaginatively to attract women, while women are more sensitive to men producing high quality humor. A lot of research supports this theory, and also the view that humor production ability is valued differ- 
ently and reveals different information for men and women - fussy women value humor as a key trait when choosing a mate, while men go to great lengths to impress women and advertise their skills in humor production (which is a predictor of the number of sexual partners) (Greengross \& Miller, 2012; Nussbaum et al., 2017).

Cheerful personality is not associated with a tendency to prefer activities for which specific and rational reasons are required, or with the inclination for a sober, object-oriented communication style (e.g. with no sarcasm or irony). It does not involve "humorless" attitudes about cheerfulness-related behaviors, role-plays, people, actions, or situations as well. With age, however, even in cheerful individuals, along with the acquisition of various life experiences, trait seriousness (which consists of the above elements) increases, which makes individuals less readily inclined to laugh or play around (Ruch et al., 1996). Young adults have significantly higher scores than older adults on both affiliative and aggressive humor, indicating that older people are less likely to engage in friendly joking and laughing with others, and are also less likely to use humor to ridicule, manipulate or to disparage others (Martin \& Ford, 2018). Previous studies on katagelasticism (defined as the joy of laughing at others), confirm these results - katagelasticists, young in particular, appreciate laughing at others and prefer to make an audience laugh at others as well (Ruch \& Proyer, 2009; Renner \& Heydasch, 2010).

Research that has been done so far proves that histrionic self-presenters describe themselves as extraverted. They draw attention to themselves, which is rewarding for extraverts. They also consider themselves as imaginative, unconventional, and less conscientious. Research results also reveal gender differences in histrionic self-presentation: men score higher on the As-If Scale than women. These differences apply to self-reports as well as behavioral indices (Renner et al., 2008). We predict, therefore, that participants who score high on the As-If Scale will also score high on extraversion and openness, and low on neuroticism. These expected correlational patterns have already been found in three studies by Renner et al. (2008). Contrary to Renner et al. (2008), who reported no correlation between histrionic selfpresentation and agreeableness in three studies, it might also be predicted that As-If presenters, who sometimes "break the rules", act inappropriately, and therefore are less norm-conforming, may be low in agreeableness. In accordance with Renner et al. (2008), we expect a negative association between the As-If-Scale and conscientiousness, a trait that involves dutiful, single-minded and disciplined behaviors that are not really compatible with the playfulness of histrionic self-presenters. Successful As-If performers should also display no (or little) fear of being laughed at, because people with gelotophobic tendencies do not engage in behaviors aimed at fascinating observers or making them laugh, such as parodying, playing or acting. Although not every pragmatist, as previously emphasized, is an As-If performer, as a high self-monitor he or she is motivated and able to change his or her behavior like an actor does. There are reasons to predict, though, that pragmatic individuals should be able to perform actions which facilitate tension creation and tension reduction in social settings. In other words, the more skillful a self-presenter is, the more inclined he or she will be to harness those skills to explicit As-If behaviors. At the same time, regardless of nationality, young male adults will describe themselves as more successful As-If performers than women and older adults.

\section{THE CURRENT RESEARCH}

The present investigation involved two studies on the construction and validation of the Polish version of the As-If-Scale (AIS), developed by Renner et al. (2008), and one study testing measurement invariance of the Polish and original (German) version of the tool. In Study $1(N=762)$ we focused on factor analysis and reliability analysis of the AIS. Study 2 ( $n=517$, part of the total $N=762$ sample) was designed to provide initial evidence regarding the validity involving correlates of the AIS with the Pragmatism Scale (PS; Wojciszke, 1984), the GELOPH<15> (a 15-item questionnaire for the subjective assessment of gelotophobia; Ruch \& Proyer, 2008b; Polish adaptation by Chłopicki et al., 2010), and the Ten Item Personality Inventory (TIPI; Gosling et al., 2003; Polish adaptation by Sorokowska et al., 2014). Finally, Study 3 ( $N=1,999$, the Polish sample $n=762$, i.e. the total number of participants from Study 1 and Study 2, and the complete German sample $n=1,237$ participants) was conducted to establish measurement invariance of two versions of the AIS, and across gender as well. Therefore, the aim of this research was to provide the Polish version of the AIS (establish its reliability and support the theoretical framework validity), and also to compare histrionic self-presentational propensities in Polish and German samples.

\section{STUDY 1}

\section{PARTICIPANTS AND PROCEDURE}

\section{AS-IF-SCALE}

The As-If-Scale (AIS) is an 8-item measure covering various forms of histrionic self-presentation, from subtle kinds (e.g. "I formulate my statements in such 
a way that they could have more than one meaning to others"), to dramatic performances ("I enjoy putting on a real show for others"). It was originally validated in German and English (Renner et al., 2008). The AIS is associated with the Acting Subscale of Snyder's Self-Monitoring Scale (SMS). The AIS score predicted several specific As-If behaviors in roleplaying assignments and was also related to rated humor, wit, and functionality. Furthermore, subjects with high scores on the AIS were able to switch quickly between different roles in a simulated talk show (Renner et al., 2008).

\section{TRANSLATION OF THE AS-IF-SCALE}

The translation followed the recommendations of International Test Commission (2017). The original As-If-Scale was translated into Polish by a German language teacher with mother tongue Polish. The semantic, idiomatic, and conceptual equivalence of the two versions was respected with diligence. An independent Germanist specialist, who was also a native speaker of Polish, back-translated it. A German native speaker compared the two versions in case of any discrepancies. Also, an independent psychologist, fluent in English but a native speaker of Polish, translated the English version of the As-If-Scale simultaneously into Polish. Translators resolved inconsistencies and agreed on the final wording.

\section{PARTICIPANTS}

We collected data from 762 Polish adults (75\% women) aged $18-66(M=21.91, S D=6.87)$. The participants had secondary (84\%) or higher $(16 \%)$ education. It was partly an online investigation, and partly a paperpencil study. The web link of the online questionnaire along with an invitation to take part in the study was sent either by e-mail to participants by fellow students who supported the authors, or via social-networking sites (SNSs). We recruited 195 participants who took part in the paper-pencil study. All of them were undergraduate students of the University of Gdansk, Gdansk University of Technology, and WSB University in Gdansk. Prior to filling out the questionnaire all participants were informed about the goal of the study and assured about confidentiality and anonymity. The questionnaire was preceded by obtaining demographic information (including age, gender and level of education) and providing instructions for everyone.

Another 50 participants (students of psychology, educational science and geography from the University of Gdansk - a subsample of the total group of participants described above) completed a paperpencil version of the As-If-Scale twice within two months to examine test-retest reliability. No incentives for participation in the study were offered.

\section{MEASURES}

The study measures were completed in Polish. Participants completed the 8-item As-If-Scale that covers various forms of histrionic acts: from subtle forms (such as irony) to dramatic performances. Participants reported how well each item described them, using a scale from 1 (doesn't apply to me at all) to 4 (applies to me completely).

\section{DATA ANALYSIS}

$\mathrm{R}$ (R Core Team, 2020) and the lavaan package (Rosseel, 2012) were used to conduct categorical confirmatory factor analysis (CCFA) using diagonally weighted least squares (DWLS) estimation. A onefactor model that was proposed by the authors of the original scale was tested. Overall model fit was evaluated using the comparative fit index (CFI), TuckerLewis index (TLI), and root mean square error of approximation (RMSEA). Although there are no universally accepted metrics of model fit (McDonald, 2010), higher values indicate better fit for the CFI and TLI, whereas lower values indicate better fit for the RMSEA. The following criteria for adequate model fit were adopted: CFI and TLI $>.95$ and RMSEA $<.08$ (Kline, 2016). Model-based reliability was estimated with coefficient omega (McDonald, 1999).

\section{RESULTS AND DISCUSSION}

CFA results for the As-If-Scale are presented in Table 1 . These results included a one-factor model, and the same model after adding covariances between error terms for two pairs of items. The one-factor structure produced an unacceptable solution, so we used modification indices to improve the model. This method revealed two pairs of items with common variances (items 1 and 2 and items 7 and 8; for content see Appendix). In both cases the investigation of the wording of those items indicated that such common variance was justified. Items 1 and 2 relate to the willingness to use specific verbal forms of histrionic self-presentation, whereas items 7 and 8 refer to the perception of one's own competences in this area. Figure 1 presents standardized loadings for the final measurement model of the Polish version of the As-If-Scale. The omega coefficient for the general AIS factor was .84.

To examine test-retest reliability, a correlation between the AIS scores measured twice (within two months) was computed. The test-retest correlation 
Table 1

CCFA fit statistics for the two structural models of the As-If-Scale

\begin{tabular}{lrrrrrr}
\hline Model & $\chi^{2}$ & $d f$ & CFI & TLI & RMSEA & RMSEA 90\% Cl \\
\hline One-factor & 320.19 & 20 & .94 & .91 & .140 & $.127-.154$ \\
$\begin{array}{l}\text { One-factor model with covariances } \\
\text { between error terms for two pairs }\end{array}$ & 69.71 & 18 & .99 & .98 & .061 & $.047-.077$ \\
of items (a1 a2, a7 a8) & & & & & & \\
\hline
\end{tabular}

\section{Figure 1}

CCFA results (standardized loading coefficients) of the As-If-Scale

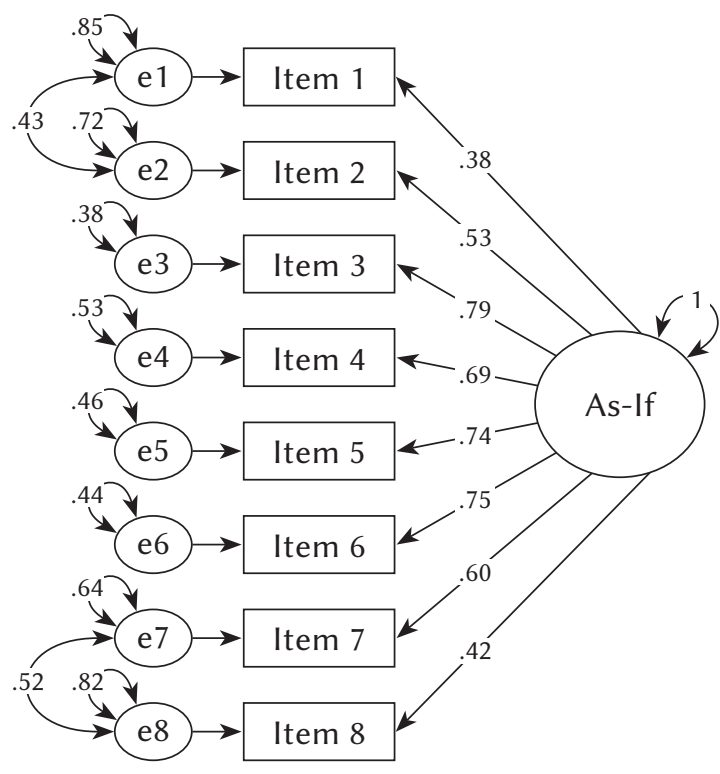

was $r_{\mathrm{tt}}=.86$, which supports strong test-retest reliability of the AIS and confirms the assumption that histrionic self-presentation is a stable trait-like style.

\section{STUDY 2}

\section{PARTICIPANTS AND PROCEDURE}

\section{PARTICIPANTS}

Five hundred and fifteen participants (part of the total Polish sample) took part in Study 2. Participants were diverse in terms of age $(M=20.77, S D=5.22)$, gender (95 men and 422 women), and education level (11\% with university degree; $89 \%$ completed secondary school or lower). All of them took part in an online survey. The web link of the online questionnaire along with an invitation to take part in the study was sent either by e-mail to participants by fellow stu- dents (from the University of Gdansk), who supported the authors, or via social-networking sites (SNSs). Prior to filling out the questionnaire all participants were informed about the goal of the study and assured about confidentiality and anonymity. The questionnaire was preceded by collection of demographic information (including age, gender and level of education) and provision of instructions for everyone.

\section{MEASURES}

After answering demographic questions and filling in the As-If-Scale, participants were asked to complete the Pragmatism Scale (PS; Wojciszke, 1984), the GELOPH $<15>$ (Ruch \& Proyer, 2008b; Polish adaptation by Chłopicki et al., 2010), and the TIPI (Gosling et al., 2003; Polish adaptation by Sorokowska et al., 2014), which are described below.

Pragmatism Scale (PS). The Pragmatism Scale measures the intensity of the subject's tendency to perceive himself/herself as a pragmatic vs. principled individual. It was derived in part from the Self-Monitoring Scale (SMS), but the theoretical basis is the reinterpretation of the self-monitoring of expressive behavior theory (Snyder \& Campbell, 1982). The scale is based on two theoretical hypotheses: the pragmatic vs. principled concept of the self and the hypothesis of the cognitive scenario. Pragmatic individuals tend to regard themselves as flexible persons who adjust their behavior to situational demands and their own goals, whereas principled individuals tend to consider their behavior as an expression of internal states and their own personality traits. The scale consists of 29 items with a dichotomous true-false response format. Seven items are translations from Snyder's SMS (1974), e.g. "I find it hard to imitate the behavior of other people", "I sometimes appear to others to be experiencing deeper emotions than I actually am", "At a party, I let others keep the jokes and stories going”. The remaining 22 items were created following the previously described understanding of the pragmatic and principled self-concepts (e.g. "With new people I can easily find a common language", "I can speak very suggestively", "I can talk interestingly", "I avoid situations that require 'playing' a role”). It was originally validated in 
Polish - the validity of the PS was shown by Wojciszke (1984). The validation demonstrated good levels of internal consistency of the PS across different samples.

GELOPH $<15>$. The GELOPH $<15>$ (Ruch \& Proyer, $2008 \mathrm{~b}$ ) is a 15 -item questionnaire for the subjective assessment of gelotophobia, that is the fear of being laughed at. It was originally validated in German, but the psychometric properties of the GELOPH $<15>$ have been published in several translations and adaptations, i.e., English (Platt et al., 2009), Polish (Chłopicki et al., 2010), Slovakian (Hrebícková et al., 2009), and Spanish (Carretero-Dios et al., 2010). Sample items are: "When others laugh in my presence, I get suspicious", "When strangers laugh in my presence, I often relate it to me personally", "I believe that I make involuntarily a funny impression on others". All items are positively keyed and the 4-point answer format ranges from 1 (strongly disagree) to 4 (strongly agree). The GELOPH $<15>$ is widely used in research (see Proyer \& Ruch, 2010; Platt et al., 2012) and it allows cut-off scores to be computed for no gelotophobia ( $\leq 2.50$ ), slight (between 2.50 and 3.00), marked or pronounced (between 3.00 and 3.50), and extreme (between 3.50 and 4.00) gelotophobia (Ruch \& Proyer, 2008b). The Polish version (Chłopicki et al., 2010) demonstrated a high level of internal consistency and is a reliable measure for the assessment of gelotophobia in research and practice.

Ten Item Personality Inventory (TIPI). The Ten Item Personality Inventory (Gosling et al., 2003) is a brief measure of the Big Five: extraversion, agreeableness, conscientiousness, neuroticism, openness to experience (Costa \& McCrae, 1992). The inventory consists of 10 statements beginning with the words: "I perceive myself as a person.... The subject is asked to respond to each self-report on a 7-point Likert scale from 1 (strongly disagree) to 7 (strongly agree). The
Polish version (TIPI-PL; Sorokowska et al., 2014) has satisfactory psychometric parameters and is suitable for personality testing in a sufficiently precise way for scientific research.

\section{DATA ANALYSIS}

Study 2 was designed to provide initial evidence for the construct validity of the AIS involving correlates of the resulting survey's scores. The Pearson correlation coefficients were calculated for the results of the As-If-Scale, the Pragmatism Scale, the GELOPH<15>, and the TIPI-PL.

\section{RESULTS AND DISCUSSION}

Table 2 shows preliminary validity evidence for the AIS scores in Study 2. In general, AIS scores correlated strongly with pragmatism $(r=.60)$, which is a closely related construct. As-If tendency negatively but weakly correlated with measure of the fear of being laughed at $(r=-.23)$. Among the Big Five personality traits, extraversion correlated most highly with the AIS $(r=.33)$, followed by a low positive correlation with openness and low negative correlations with neuroticism and agreeableness. These results confirm our predictions - successful As-If performers describe themselves as good entertainers and show acting skills, which are necessary for histrionic self-presentation. At the same time, they are more resistant to signals of being ridiculed by others, and less anxious. They describe themselves as creative, imaginative, unconventional and less norm-conforming. Contrary to our expectations, however, no association between the As-If-Scale and conscientiousness was found.

\section{Table 2}

Descriptive statistics and correlations

\begin{tabular}{|c|c|c|c|c|c|c|c|c|c|c|}
\hline Variable & M & $S D$ & 1 & 2 & 3 & 4 & 5 & 6 & 7 & 8 \\
\hline 1. As-If & 16.99 & 4.94 & - & & & & & & & \\
\hline 2. Pragmatism & 19.25 & 4.91 & $.60^{* *}$ & - & & & & & & \\
\hline 3. Fear & 33.51 & 10.08 & $-.23^{* *}$ & $-.25^{* *}$ & - & & & & & \\
\hline 4. Extraversion & 9.11 & 3.44 & $.33^{* *}$ & $.41^{* *}$ & $-.63^{* *}$ & - & & & & \\
\hline 5. Agreeableness & 10.23 & 2.67 & $-.10^{*}$ & -.01 & -.08 & .08 & - & & & \\
\hline 6. Conscientiousness & 9.01 & 3.43 & -.05 & .03 & $-.14^{* *}$ & $.18^{* *}$ & $.12^{* *}$ & - & & \\
\hline 7. Neuroticism & 10.15 & 3.33 & $-.14^{*}$ & $-.20^{* *}$ & $.49^{* *}$ & $-.50^{* *}$ & $-.18^{* *}$ & $-.21^{* *}$ & - & \\
\hline $\begin{array}{l}\text { 8. Openness to } \\
\text { experience }\end{array}$ & 10.15 & 2.58 & $.24^{* *}$ & $.25^{* *}$ & $-.36^{* *}$ & $.36^{* *}$ & .07 & -.04 & $-.13^{* *}$ & - \\
\hline
\end{tabular}




\section{STUDY 3}

\section{PARTICIPANTS AND PROCEDURE}

\section{PARTICIPANTS}

To determine whether Polish and German versions of the AIS measure the same constructs, i.e. demonstrate measurement invariance, we used existing data from both countries. Using these data, we tested for gender measurement invariance as well. The Polish sample consists of $n=762$ participants described in Study 1 and 2. The German sample consists of $n=1,237$ participants (924 women and 313 men aged $16-67, M=32.32, S D=10.07$ ) from four previously published studies (see Renner et al., 2008; Renner \& Heydasch, 2010; Renner \& Manthey, 2018).

\section{DATA ANALYSIS}

To determine whether the AIS measure the same construct in both countries, as well as across gender, we assessed cross-country equivalence through multigroup confirmatory factor analysis (MGCFA). Usually, researchers estimate three levels of invariance, which are defined by parameters that are constrained to be equal across samples (see Vandenberg \& Lance, 2000). Configural invariance requires that a given set of indicators are predicted by the same latent variables with the same pattern of factor loadings; metric invariance requires that factor loadings are equal across the groups; and scalar invariance requires that factor loadings and all thresholds (in the case of a categorical confirmatory factor analysis) are equal across the groups. We used the same criteria as for CFA to assess models' goodness of fit. Next, to identify metric and scalar measurement invariance, we used the cutoff criteria suggested by Chen (2007): $\triangle \mathrm{CFI}<0.01$ and $\triangle$ RMSEA $<0.015$. We used R (R Core Team, 2020) and the lavaan package (Rosseel, 2012) to conduct cate- gorical confirmatory factor analysis (CCFA) using diagonally weighted least squares (DWLS) estimation.

In the next step, we performed a univariate analysis of variance comparing the average AIS scores in six groups: 2 (German versus Polish) $\times 2$ (women versus men $) \times 2$ (participants under 25 years of age versus participants who are 25 or older).

\section{RESULTS AND DISCUSSION}

Table 3 presents the global fit coefficients for the three levels of measurement invariance (configural, metric, and scalar) for the AIS across Polish and German samples, as well as across gender. As can be seen in Table 3, the AIS scale displayed configural, metric, and scalar invariance across the countries and gender, according to the cut-off criteria suggested by Chen (2007). The only exception is the $\triangle$ RMSEA criterion, which is slightly exceeded when scalar measurement invariance across the country was tested. However, given that in the case of low complex models this criterion may be too sensitive (see Kenny et al., 2015), we were quite satisfied that the CFI criterion was clearly met for scalar measurement invariance. Finally, based on the results, we decided that the AIS meets the requirements of measurement invariance in both countries tested, as well as in both groups of males and females.

The results of a univariate analysis of variance showed a significant main effect of country: $F(1)=15.46, p<.001$, gender: $F(1)=40.18, p<.001$, as well as age group: $F(1)=52.51, p<.001$ on the AIS, when all three variables were included in the comparison. The results showed that participants who are 25 or older, regardless of nationality or gender, score lower on the AIS $(M=16.26, S D=4.47)$ compared to younger participants $(M=17.82, S D=5.00)$, $t(1960)=7.33, p<.01, \eta^{2}=.01$. Moreover, males regardless of nationality or age groups score higher on the AIS $(M=18.39, S D=4.72)$ compared to female partici-

\section{Table 3}

Global fit measures in measurement invariance tests for the As-If-Scale

\begin{tabular}{|c|c|c|c|c|c|c|c|}
\hline Grouping variable & Level of invariance & $\chi^{2}$ & $d f$ & CFI & RMSEA & $\Delta \mathrm{CFI}$ & $\triangle \mathrm{RMSEA}$ \\
\hline \multirow[t]{3}{*}{ Country } & Configural & 144.89 & 36 & .99 & .055 & - & - \\
\hline & Metric & 170.82 & 43 & .99 & .055 & .000 & .000 \\
\hline & Scalar & 421.26 & 58 & .98 & .079 & .001 & .024 \\
\hline \multirow[t]{3}{*}{ Gender } & Configural & 108.24 & 36 & .99 & .045 & - & - \\
\hline & Metric & 122.77 & 43 & .99 & .043 & .000 & .002 \\
\hline & Scalar & 203.89 & 58 & .99 & .050 & .000 & .007 \\
\hline
\end{tabular}


pants $(M=16.58, S D=4.80), t(1996)=-7.44, p<.01$, $\eta^{2}=.01$. The ANOVA results showed no significant interaction effects (country ${ }^{*}$ gender: $F=1.28, p=.259$; country*age: $F=.29, p=.593$; gender*age: $F=.31$, $p=.579$; country ${ }^{*}$ gender ${ }^{*}$ age: $F=1.32, p=.251$ ). However, the further post-hoc test showed that young German men score significantly higher on the AIS $(M=20.66, S D=4.87)$ than their Polish counterparts $(M=18.56, S D=4.80), t(238)=3.24, p<.01, \eta^{2}=.01$. This effect was not repeated either in the group of older participants or in the group of women.

\section{GENERAL DISCUSSION}

The present research aimed to translate and confirm the psychometric properties of a Polish As-If-Scale, as well as to test the measurement invariance of the Polish and the original (German) version of the instrument, and to analyze the differences in histrionic self-presentation style among Poles and Germans. Overall, the results provide support for the reliability of the scale as its properties are similar to those of the German version. The original As-If-Scale is a onefactor model. In the Polish sample the one-factor structure produced an unacceptable solution, but we used modification indices to improve the model. This method revealed two pairs of items with common variances (items 1 and 2 and items 7 and 8). In both cases the investigation of the wording of those items indicated that such common variance was justified. Items 1 and 2 relate to the willingness to use specific verbal forms of histrionic self-presentation, whereas items 7 and 8 refer to the perception of one's own competences in this area.

The findings of Study 1 also confirmed the assumption that histrionic self-presentation is a stable trait-like style, as the study demonstrated high testretest stability of the scale. As expected, the AIS was positively associated with the Pragmatism Scale. The results support the idea that pragmatism, with its acting content, is needed to perform a histrionic selfpresentation style successfully as people with pragmatic selves and the respective acting abilities are flexible enough to adjust their behavior to situational demands, some of which may be gaining attention of other people, making them laugh, or creating and reducing tension in themselves and the audience. Although conceptually similar, these two concepts (pragmatism and histrionic self-presentation) have some distinct differences. Pragmatists usually function best if their behaviors are not perceived as roleplays, which is not the case with As-If performers - their role-playing has to be explicit in order to be successful. Moreover, if the As-If mode is recognized wrongly (or not recognized at all) by the audience, some negative consequences may emerge, such as feeling hurt by what an As-If performer does, or per- ceiving him or her as too theatrical or even crazy. Pragmatists, in turn, act according to the demands and requirements of the situation they are in - their behavior is always appropriate, and in response to situational cues (for details see Renner et al., 2008). In the Polish sample, as in the original studies, a positive correlation between AIS and extraversion was obtained as well as between AIS and openness to experience. Thus, individuals achieving high scores in the AIS are more imaginative, unconventional and creative than their low AIS counterparts. Also, they are more talkative and adept at telling funny stories. But above all, they are able and more willing to entertain others, and describe themselves as enthusiastic, sociable, lively, active, assertive, and tending to enjoy human interactions. They feel good being the center of attention. There were also small negative correlations between the AIS and neuroticism as well as agreeableness. Successful As-If performers are therefore less anxious, apprehensive, or guilt feeling. They are probably characterized by less stage fright, and they do not focus so much on detecting potential threats in the environment. As they do not give so much attention to the situational appropriateness and desired public appearance, their behavior can be sometimes perceived as unfriendly or even aggressive. Capable of using mockery and irony, they are more provocative, less norm-conforming, and less responsive to other people's expectations. Although an expected, negative (but weak) correlation between the AIS and the GELOPH $<15>$ (measuring the intensity of the fear of being laughed at) was obtained, the relationship between these two constructs seems to be more complex. As shown by the studies, gelotophobes do not display the ability to quickly retort, do not have a well-developed humorous style and do not infect others with laughter (Ruch et al., 2009). Still, some of them are quite willing to laugh or entertain other people, as there are some components of humor in which gelotophobes actually indulge, or even excel (Ruch, 1995). It is their underestimation of humor production abilities (which stems from their low selfesteem manifested in their protective self-presentation style, Renner \& Heydasch, 2010) which results in not considering using them in everyday life rather than a pure lack of wit or humor. Research shows that across the nations tested so far there are about $90 \%$ of individuals without any fear of being laughed at (Platt et al., 2012). However, in the Polish sample $33.88 \%$ of women and $30.52 \%$ of men have at least a slight fear of being laughed at. Even more notably, up to $4 \%$ of the sample exhibits extreme gelotophobia (compared to less than $1 \%$ in other populations). The reasons for that might be the hierarchical social structure (individuals with lower socioeconomic status experience more gelotophobia), maintaining differences in status and privileges, introversion and higher neuroticism, and preferences for values such 
as conformity, social order, and respect for tradition (for details see Chłopicki et al., 2010). In our cross-national comparison, we also found gender differences in histrionic self-presentation - men scored higher on the AIS than women (regardless of nationality and age), which is consistent with the results of previous studies (e.g. Renner \& Heydasch, 2010). Different mating strategies (production of humor by men and its appreciation by women) or having more role models around to draw inspiration from (there are more men than women among stand-up comedians) may serve as a plausible explanation. Also, participants younger than 25 scored higher on the AIS than their older counterparts, which indicates that young people are more eager to transform daily situations into dramatic scenes and to use their body (through grimaces, gestures, and postures) and language (e.g. by modulating their voice) to attract the attention of others and make them laugh. Previous studies on katagelasticism (defined as the joy of laughing at others), which is positively correlated with As-If behaviors, confirm these results. Katagelasticists, young in particular, appreciate laughing at others and prefer to make an audience laugh at others as well (Ruch \& Proyer, 2009; Renner \& Heydasch, 2010).

Despite the fact that the study confirmed the properties of the original scale, there is still a lot to be done to make sure that the As-If-Scale can be perceived as a useful and reliable research tool for assessing the histrionic self-presentation style for the Polish speaking community. As the study on this particular kind of self-presentation has only started recently in Poland, some issues are still left to be addressed. First of all, as the results reported here are based only on self-reports, some behavioral indices of explicit As-If behaviors are needed to verify and support correlates of the histrionic self-presentation style, as well as to determine the predictive validity of the As-If-Scale. Moreover, as our study participants are predominantly female, young, and educated (most of them are graduates of at least secondary schools) we have to be very careful in applying the results to the general population. Studying a more representative group, diverse in terms of age and education, would of course be beneficial. In addition, reports from many sources unanimously confirm the thesis that most Poles are not too keen to engage in any self-promotional actions (e.g. Szarota, 2006; Wierzbicka, 1999). They prefer to behave naturally, which usually means that they do not smile or laugh, but indulge in constant complaining instead (Wojciszke \& Baryła, 2002). This, along with gelotophobic tendencies (Chłopicki et al., 2010), raises the question why they engage in As-If behaviors at all, and what the gains and costs of it are. If explicit As-If behaviors are hazardous anyway (e.g. when the As-If mode of histrionic role-plays is not recognized by an audience), it may imply that they take a double risk: being taken for ridiculous or mad, and also severely laughed at. This suggests that the results obtained by Poles on the As-If-Scale should be lower than those obtained by other nationalities. And indeed, in our cross-national comparison, we found that young German males scored significantly higher than their Polish counterparts.

Finally, abilities such as playing roles in order to create tension on one hand, and to relieve stress on the other, are related to social skills that require exercise. Specifically, the Internet Generation, whose representatives were born not earlier than in 1998, does not develop social skills to the extent that previous generations did. Young people are less sociable than Generation X or Millennials, and rarely participate in face-to-face interactions that are more or less focused on a specific goal (Twenge, 2018). This may result not only in problems in reading basic emotions such as happiness, sadness, anger or fear based on the facial expressions, but also in decoding more subtle indicators of As-If behaviors (grimaces, postures, voice modulation or irony). The Internet Generation is much less experienced in social contacts, personal communication or problem solving. Will the inevitable failures expected at important moments of their lives, such as job interviews, making friends, or communication with lecturers at universities, also occur in more informal situations involving As-If behaviors? This question, like the previous ones, is still left to be answered.

\section{REFERENCES}

Alicke, M. D., Braun, J. C., Glor, J. E., Klotz, M. L., Magee, J., Sederhoim, H., \& Siegel, R. (1992). Complaining behavior in social interaction. Personality and Social Psychology Bulletin, 18, 286-295. https// doi.org/10.1177/0146167292183004

American Psychiatric Association (2013). Diagnostic and statistical manual of mental disorders (DSM-5). Fifth edition. APA.

Baumeister, R. F. (1982). A self-presentational view of social phenomena. Psychological Bulletin, 91, 3-26. https://doi.org/10.1037/0033-2909.91.1.3

Bressler, E. R., \& Balshine, S. (2006). The influence of humor on desirability. Evolution and Human Behavior, 27, 29-39. https://doi.org/10.1016/j.evolhumbehav.2005.06.002

Carretero-Dios, H., Proyer, R. T., Ruch, W., \& Rubio, V. J. (2010). The Spanish version of the GELOPH<15>: Properties of a questionnaire for the assessment of the fear of being laughed at. International Journal of Clinical and Health Psychology, 10, 345-357.

Chen, F. F. (2007). Sensitivity of goodness of fit indexes to lack of measurement invariance. Structural Equation Modeling: A Multidisciplinary Journal, 14, 464504. https://doi.org/10.1080/10705510701301834 
Chłopicki, W., Radomska, A., Proyer, R. T., \& Ruch, W. (2010). The assessment of the fear of being laughed at in Poland: Translation and first evaluation of the Polish GELOPH<15>. Polish Psychological Bulletin, 41, 172-181. https://doi.org/10.2478/v10059010-0022-2

Cohen, A. R. (1959). Some implications of self-esteem for social influence. In C. Hovland \& I. Janis (Eds.), Personality and persuasibility (pp. 102-120). Yale University Press.

Costa. P.T., Jr, \& McCrae, R. R. (1992). Four ways five factors are basic. Personality and Individual Differences, 13, 653-665. https://doi.org/10.1016/01918869(92)90236-I

DeYoung, C., Quilty, L. C., \& Peterson, J. B. (2007). Between facets and domains: 10 aspects of the Big Five. Journal of Personality and Social Psychology, 93, 880-896. https://doi.org/10.1037/00223514.93.5.880

Dionigi, A. (2016). Personality of clown doctors. An exploratory study. Journal of Individual Differences, 37, 49-55. https://doi.org/10.1027/1614-0001/a000187

Dupree, C. H., \& Fiske, S. T. (2019). Self-presentation in interracial settings: The competence downshift by white liberals. Journal of Personality and Social Psychology, 117, 579-604. https://doi.org/10.1037/ pspi0000166

Eysenck, M. W., \& Derakshan, N. (2011). New perspectives in attentional control theory. Personality and Individual Differences, 50, 955-960. https://doi. org/10.1016/j.paid.2010.08.019

Gangestad, S. W., \& Snyder, M. (2000). Self-monitoring: Appraisal and reappraisal. Psychological Bulletin, 126, 530-555. https://doi.org/10.1037//00332909.126.4.530

Goffman, E. (1959). The presentation of self in everyday life. Penguin.

Gosling, S. D., Rentfrow, P. J., \& Swann, W. B., Jr (2003). A very brief measure of the Big Five personality domains. Journal of Research in Personality, 37, 504-528. https://doi.org/10.1016/S00926566(03)00046-1

Greengross, G., Martin, R. A., \& Miller, G. F. (2011). Personality traits, intelligence, humor styles, and humor production ability of professional stand-up comedians compared to college students. Psychology of Aesthetics, Creativity and the Arts, 6, 74-82. https://doi.org/10.1037/a0025774

Greengross, G., \& Miller, G. F. (2009). The Big Five personality traits of professional comedians compared to amateur comedians, comedy writers, and college students. Personality and Individual Differences, 47, 79-83. https://doi.org/10.1016/j.paid. 2009.01.045

Greengross, G., \& Miller, G. F. (2012). Humor ability reveals intelligence, predicts mating success, and is higher in males. Intelligence, 39, 188-192. http:// dx.doi.org./10.1016/j.intell.2011.03.006
Hrebícková, M., Ficková, E., Klementová, M., Ruch, W., \& Proyer, R. T. (2009). Strach ze zesmesnení: Ceská a slovenská verze dotazníku pro zjistování gelotofobie [The fear of being laughted at: The Czech and Slovak version of the GELOPH<15> for the assessment of gelotophobia]. Ceskoslovenská Psychologie, 53, 469-480.

International Test Commission (2017). The ITC guidelines for translating and adapting tests (2nd ed.). Retrieved from www.intestcom.org

Jones, E. E., \& Wortman, C. (1973). Ingratiation: an attributional approach. General Learning Press.

Jones, E. E., \& Pittman, T. (1982). Toward a general theory of strategic self-presentation. In J. Suls (Ed.), Psychological perspectives on the self (Vol. 1, pp. 231-262). Erlbaum.

Jones, E. E., Rhodewalt, F., Berglas, S., \& Skelton, J. A. (1981). Effects of strategic self-presentation on subsequent self-esteem. Journal of Personality and Social Psychology, 41, 407-421. https://doi.org/10.1037/ 0022-3514.41.3.407

Kenny, D. A., Kaniskan, B., \& McCoach, D. B. (2015). The performance of RMSEA in models with small degrees of freedom. Sociological Methods \& Research, 44, 486-507. https://doi.org/10.1177/0049124 114543236

Kline, R. B. (2016). Principles and practice of structural equation modeling (4th ed.). Guilford Press.

Köhler, G., \& Ruch, W. (1996). Sources of variance in current sense of humor inventories: How much substance, how much method variance? Humor: International Journal of Humor Research, 9, 363398. https://doi.org/10.1515/humr.1996.9.3-4.363

Koppel, M. A., \& Sechrest, L. (1970). A multitraitmultimethod matrix analysis of sense of humor. Educational and Psychological Measurement, 30, 77-85. https://doi.org/10.3102/00346543046003407

Kowalski, R. M. (1996). Complaints and complaining: Functions, antecedents, and consequences. Psychological Bulletin, 119, 179-196. https://doi.org/ 10.1037/0033-2909.119.2.179

Kowalski, R. M. (2002). Whining, griping, and complaining: Positivity in the negativity. Journal of Clinical Psychology, 58, 1023-1035. https://doi.org/ 10.1002/jclp. 10095

Leary, M. R. (1995). Self-presentation: Impression management and interpersonal behavior. Westview Press.

Lundy, D. E., Tan, J., \& Cunningham, M. R. (1998). Heterosexual romantic preferences: The importance of humor and physical attractiveness for different types of relationships. Personal Relationships, 5, 311-325. https://doi.org/10.1111/j.1475-6811.1998. tb00174.x

Martin, R. A., \& Ford, T. E. (2018). The psychology of humor. An integrative approach. Elsevier, Academic Press.

McDonald, R. P. (2010). Structural models and the art of approximation. Perspectives on Psychological 
Science, 5, 675-686. https://doi.org/10.1177/174569 1610388766

McDonald, R. P. (1999). Test theory: a unified treatment. Erlbaum.

Nussbaum, E. C., Silvia, P. J., \& Beaty, R. E. (2017). Ha ha? Assessing individual differences in humor production ability. Psychology of Aesthetics, Creativity \& the Arts, 11, 231-241. https://doi.org/10.1037/ aca0000086

Platt, T. (2008). Emotional responses to ridicule and teasing: Should gelotophobes react differently? Humor: International Journal of Humor Research, 21, 105-128. https://doi.org/10.1515/HUMOR.2008.005

Platt, T., Proyer, R. T., \& Ruch, W. (2009). Gelotophobia and bullying: The assessment of the fear of being laughed at and its application among bullying victims. Psychology Science Quarterly, 51, 135-147.

Platt, T., Ruch, W., Hofmann, J., \& Proyer, R. T. (2012). Extreme fear of being laughed at: Components of gelotophobia. Israeli Journal of Humor Research, 1, 86-106.

Proyer, R. T., \& Ruch, W. (2010). Dispositions towards ridicule and being laughed at: Current research on gelotophobia, gelotophilia, and katagelasticism. Psychological Test and Assessment Modeling, 52, 49-59.

R Core Team (2020). R: a language and environment for statistical computing. Retrieved from https:// www.R-project.org

Radomska, A., \& Tomczak, J. (2010). Gelotophobia, self-presentation styles, and psychological gender. Psychological Test and Assessment Modeling, 52, 191-201.

Renner, K. H., Enz, S., Friedel, H., Merzbacher, G., \& Laux, L. (2008). Doing as if: The histrionic self-presentation style. Journal of Research in Personality, 42, 1303-1322. https://doi.org/10.1016/j.jrp.2008.04.005

Renner, K. H., \& Heydasch, T. (2010). Performing humor: On the relations between self-presentation styles, gelotophobia, gelotophilia, and katagelasticism. Psychological Test and Assessment Modeling, 52, 171-190.

Renner, K. H., \& Manthey, L. (2018). Relations of dispositions toward ridicule and histrionic selfpresentation with quantitative and qualitative humor creation abilities. Frontiers in Psychology, 9, 78. https://doi.org/10.3389/fpsyg.2018.00078

Rogers, C., \& Dymond, R. (1954). Psychotherapy and personality change. University of Chicago Press.

Rosseel, Y. (2012). lavaan: an R package for structural equation modeling. Journal of Statistical Software, 48, 1-36. https://doi.org/10.18637/jss.v048.i02

Ruch, W. (1995). A psycholexical study of the "sense of humor": Taxonomizing German humor related nouns. Paper presented at the Thirteenth International Humor Conference, Birmingham, July 31-August 4.

Ruch, W., Beermann, U., \& Proyer, R. T. (2009). Investigating the humor of gelotophobes: Does feeling ridiculous equal being humorless? Humor: International Journal of Humor Research, 22, 111-143. https://doi.org/10.1515/HUMR.2009.006

Ruch, W., Köhler, G., \& Van Thriel (1996). Assessing the "humorous temperament": Construction of the facet and standard trait forms of the StateTrait-Cheerfulness-Inventory - STCI. Humor: International Journal of Humor Research, 9, 303-339. https://doi.org/10.1515/humr.1996.9.3-4.303

Ruch, W., \& Hofmann, J. (2012). A temperament approach to humor. In P. Gremigni (Ed.), Health psychology research focus. Humor and health promotion (pp. 79-112). Nova Biomedical Books.

Ruch, W., \& Proyer, R. T. (2008a). The fear of being laughed at: Individual and group differences in gelotophobia. Humor: International Journal of $\mathrm{Hu}$ mor Research, 2, 47-67. https://doi.org/10.1515/ HUMOR.2008.002

Ruch, W., \& Proyer, R. T. (2008b). Who is gelotophobic? Assessment criteria for the fear of being laughed at. Swiss Journal of Psychology, 67, 19-27. https://doi.org/10.1024/1421-0185.67.1.19

Ruch, W., \& Proyer, R. T. (2009). Extending the study of gelotophobia: On gelotophiles and katagelasticists. Humor: International Journal of Humor Research, 22, 183-212. https://doi.org/10.1515/HUMR.2009.009

Scopelliti, I., Loewenstein, G., \& Vosgerau, J. (2015). You call it "selfexuberance"; I call it "bragging": Miscalibrated predictions of emotional responses to self-promotion. Psychological Science, 26, 903914. https://doi.org/10.1177/0956797615573516

Schlenker, B. R. (1980). Impression management: The self-concept, social identity, and interpersonal relations. Brooks/Cole.

Schlenker, B. R., \& Pontari, B. A. (1973). The strategic control of information: Impression management and self-presentation in daily life. In A. Tesser, R. B. Felson, \& J. M. Suls (Eds.), Psychological perspectives on self and identity (pp. 199-232). American Psychological Association.

Sezer, O., Gino, F., \& Norton, M. I. (2018). Humblebragging: a distinct and ineffective self-presentation strategy. Journal of Personality and Social Psychology, 114, 52-74. https://doi.org/10.1037/pspi0000108

Snyder, M. (1974). Self-monitoring of expressive behavior. Journal of Personality and Social Psychology, 30, 526-537. https://doi.org/10.1037/h0037039

Snyder, M., \& Campbell, B. H. (1982). Self-monitoring: The self in action. In J. Suls (Ed.), Psychological perspectives on the self (Vol. 1, pp. 185-207). Erlbaum.

Sorokowska, A., Słowińska, A., Zbieg, A., \& Sorokowski, P. (2014). Polska adaptacja testu Ten Item Personality Inventory (TIPI) - TIPI-PL - wersja standardowa i internetowa. [Polish adaptation of Ten Item Personality Inventory - TIPI-PL - standard and Internet version]. WrocLab.

Steptoe, A., Malik, F., Pay, C., Pearson, P., Price, C., \& Win, Z. (1995). The impact of stage fright on stu- 
dent actors. British Journal of Psychology, 86, 27-39. https://doi.org/10.1111/j.2044-8295.1995.tb02544.x

Szarota, P. (2006). Psychologia uśmiechu. Analiza kulturowa [The psychology of a smile. Cultural analysis]. Gdańskie Wydawnictwo Psychologiczne.

Szmajke, A. (1995). Popularność w grupie a styl autoprezentacji [Popularity in the group and the style of self-presentation]. Psychologia Wychowawcza, 38, 385-392.

Titze, M. (1996). The Pinocchio Complex: Overcoming the fear of laughter. Humor \& Health Journal, 5, 1-11.

Titze, M. (2009). Gelotophobia: The fear of being laughed at. Humor: International Journal of $\mathrm{Hu}^{-}$ mor Research, 22, 27-48. https://doi.org/10.1515/ HUMR.2009.002

Twenge, J. M. (2018). iGen: Why today's super-connected kids are growing up less rebellious, more tolerant, less happy - and completely unprepared for adulthood - and what that means for the rest of us. Simon \& Schuster.

Vandenberg, R. J., \& Lance, C. E. (2000). A review and synthesis of the measurement invariance literature: Suggestions, practices, and recommendations for organizational research. Organizational Research Methods, 3, 4-70. https://doi.org/10. 1177/109442810031002

Vohs, K. D., Baumeister, R. F., \& Ciarocco, N. J. (2005). Self-regulation and self-presentation: Regulatory resource depletion impairs impression management and effortful self-presentation depletes regulatory resources. Journal of Personality and Social Psychology, 88, 632-657. https://doi.org/10. 1037/0022-3514.88.4.632

Wierzbicka, A. (1999). Język - umyst - kultura [Language - mind - culture]. PWN.

Wojciszke, B. (1984). Skala pragmatyzmu - treść i charakterystyka psychometryczna [Pragmatism Scale - the content and psychometric properties]. Przeglad Psychologiczny, 27, 725-743.

Wojciszke, B., \& Baryła, W. (2002). Jak odstrzelić sobie nogę: funkcje i konsekwencje narzekania [How to shoot a leg off: Functions and consequences of complaining]. Kolokwia Psychologiczne, 10, 213-235. 
APPENDIX

English, German and Polish versions of the As-If-Scale items

\begin{tabular}{|c|c|c|c|}
\hline \multirow[t]{2}{*}{ Item } & \multicolumn{3}{|c|}{ Language versions } \\
\hline & English & German & Polish \\
\hline 1 & $\begin{array}{l}\text { I formulate my statements } \\
\text { in such a way that they } \\
\text { could have more than one } \\
\text { meaning to others. }\end{array}$ & $\begin{array}{l}\text { Ich gestalte meine Aussagen } \\
\text { gerne so, dass sie für andere } \\
\text { Personen mehrdeutig sind. }\end{array}$ & $\begin{array}{c}\text { Lubię konstruować moje } \\
\text { wypowiedzi w taki sposób, } \\
\text { aby były niejednoznaczne } \\
\text { dla innych. }\end{array}$ \\
\hline 2 & $\begin{array}{l}\text { When I say something, } \\
\text { I often change my voice to } \\
\text { indicate that I do not really } \\
\text { mean what I say. }\end{array}$ & $\begin{array}{l}\text { Wenn ich etwas sage, verändere } \\
\text { ich häufig meine Stimme, um } \\
\text { den anderen zu verdeutlichen, } \\
\text { dass ich das jetzt eigentlich } \\
\text { nicht so meine. }\end{array}$ & $\begin{array}{c}\text { Kiedy coś mówię, często } \\
\text { zmieniam swój głos, aby inni } \\
\text { wiedzieli, że tak naprawdę } \\
\text { mam na myśli coś innego, niż } \\
\text { wyrażam. }\end{array}$ \\
\hline 3 & $\begin{array}{l}\text { When I tell stories, I act out } \\
\text { the roles of the different } \\
\text { participants by imitating } \\
\text { their body language and the } \\
\text { way they talk. }\end{array}$ & $\begin{array}{l}\text { Wenn ich anderen eine Ge- } \\
\text { schichte o.ä. erzähle, dann spiele } \\
\text { ich dabei die verschiedenen } \\
\text { beteiligten Personen nach, in- } \\
\text { dem ich ihre Körpersprache und } \\
\text { Redeweise imitiere. }\end{array}$ & $\begin{array}{l}\text { Jeśli opowiadam jakąś histo- } \\
\text { rię innym, „gram” różnymi } \\
\text { zaangażowanymi w nią oso- } \\
\text { bami, naśladując ich sposób } \\
\text { mówienia i język ciała. }\end{array}$ \\
\hline 4 & $\begin{array}{c}\text { In everyday interactions, } \\
\text { I can cause others to per- } \\
\text { form small role plays with } \\
\text { me so that it almost seems } \\
\text { as if we are staging a short } \\
\text { play. }\end{array}$ & $\begin{array}{l}\text { Ich kann in alltäglichen Situati- } \\
\text { onen andere dazu bringen, mit } \\
\text { mir zusammen kleine Rollen- } \\
\text { spiele aufzuführen, so dass fast } \\
\text { der Eindruck entsteht, als ob wir } \\
\text { gemeinsam ein kurzes Theater- } \\
\text { stück spielen würden. }\end{array}$ & $\begin{array}{l}\text { W codziennych sytuacjach } \\
\text { potrafię sprawić, by inni od- } \\
\text { grywali ze mną małe role } \\
\text { tak, aby powstało wrażenie, } \\
\text { że gramy wspólnie krótkie } \\
\text { przedstawienie. }\end{array}$ \\
\hline 5 & $\begin{array}{l}\text { I enjoy parodying other } \\
\text { people. }\end{array}$ & $\begin{array}{l}\text { Mir macht es Spaß, andere } \\
\text { Personen zu parodieren. }\end{array}$ & $\begin{array}{l}\text { Lubię parodiować innych } \\
\text { ludzi. }\end{array}$ \\
\hline 6 & $\begin{array}{l}\text { I enjoy putting on a real } \\
\text { show for others. }\end{array}$ & $\begin{array}{c}\text { Es macht mir Spaß, anderen } \\
\text { Personen gegenüber eine } \\
\text { richtige Show abzuziehen. }\end{array}$ & $\begin{array}{l}\text { Lubię odegrać prawdziwy } \\
\text { show przed innymi ludźmi. }\end{array}$ \\
\hline 7 & $\begin{array}{l}\text { I know exactly how to } \\
\text { fascinate my audience. }\end{array}$ & $\begin{array}{c}\text { Ich weiß genau, wie ich meine } \\
\text { Zuhörer fasziniere. }\end{array}$ & $\begin{array}{c}\text { Dokładnie wiem, jak zafascy- } \\
\text { nować swoich słuchaczy. }\end{array}$ \\
\hline 8 & $\begin{array}{l}\text { I can put others in a good } \\
\text { mood. }\end{array}$ & $\begin{array}{c}\text { Ich kann andere Leute in gute } \\
\text { Stimmung bringen. }\end{array}$ & $\begin{array}{l}\text { Potrafię wprawić innych } \\
\text { w dobry nastrój. }\end{array}$ \\
\hline
\end{tabular}

